Max-Planck-Institut für demografische Forschung

Max Planck Institute for Demographic Research

Konrad-Zuse-Strasse 1 - D-18057 Rostock · GERMANY

Tel +49 (0) 3812081 - 0; Fax +49 (0) 3812081 - 202;

http://www.demogr.mpg.de

MPIDR WORKING PAPER WP 2005-005

MARCH 2005

\title{
A study on policies and practices in selected countries that encourage childbirth: The case of Sweden
}

Gunnar Andersson (andersson@ demogr.mpg.de)

This working paper has been approved for release by: Andres Vikat (vikat@demogr.mpg.de)

Deputy Head of the Laboratory of Contemporary European Fertility and Family Dynamics.

(C) Copyright is held by the authors.

Working papers of the Max Planck Institute for Demographic Research receive only limited review. Views or opinions expressed in working papers are attributable to the authors and do not necessarily reflect those of the Institute. 




GA, 18 February 2005

\section{A Study on Policies and Practices in Selected Countries that Encourage Childbirth: The Case of Sweden ${ }^{1}$}

by Gunnar Andersson

\section{SUMMARY}

Swedish family policies are not directly aimed at encouraging childbirth. Their main goal has rather been to support women's labour-force participation and to promote gender equality. The focus is to strengthen individuals so that they are able to pursue their family and occupational tracks without being too strongly dependent on other individuals. The reconciliation of family and working life of women has been facilitated by (i) individual taxation, which makes it less attractive for couples to pursue gendered segregation of work and care, (ii) an income-replacement based parental-leave system, which gives women incentives to establish themselves in the labour market before considering childbirth, and (iii) subsidized child-care, which allows women to return to work after parental leave. Fertility has fluctuated during recent decades but, as in the other Nordic countries with a similar welfare-state setup, it has stayed well above the European average. The Swedish context clearly is conducive to such "highest-low" fertility. In this study, I show that institutional factors seem to be far more decisive than cultural ones in shaping childbearing behaviour, and demonstrate some specific impacts of family policies on childbearing dynamics.

\footnotetext{
${ }^{1}$ This paper is a contribution to the "Consultancy Study on Population Related Matters - A Study on Policies and Practices in Selected Countries that Encourage Childbirth" for the Government of Hong Kong Special Administrative Region.
} 


\section{BACKGROUND}

In demographic research, Sweden often stands out as a country of reference. This stems from the combination of two features. First, Sweden is a fore-runner in the development of important aspects of family-demographic behaviour, and second, it has some of the best demographic data in the world. The experience of Sweden is also of interest because it has been innovative in terms of policy development. In the 1970s and 1980s, changes in women's position in society motivated the introduction of a wide range of policies with the aim of achieving greater compatibility between women's family and working roles. Subsequently, public policies have focused more explicitly on men and their reconciliation of family with working life.

It is very common to relate the relatively high fertility of Sweden and its Nordic neighbours to the setup of its policies and the characteristics of the Nordic welfare regime. The recuperation of fertility levels that occurred in the Nordic countries during the $1980 \mathrm{~s}$ is often considered as related to the introduction and extension of various family-related policies. During the beginning of the 1990s, the then remarkably high fertility of Sweden attracted particular attention. The role of increased compatibility between female employment and parenthood in Sweden - and elsewhere in Scandinavia - has been stressed by authors such as Moen (1989), Sundström (1991), Haas (1992), Pauti (1992), Sundström and Stafford (1992), Bernhardt (1993), B. Hoem (1993), Ellingsæter and Rønsen (1996), Rindfuss and Brewster (1996), Hoem and Hoem (1996, 1999), Brewster and Rindfuss (2000), Oláh (2003), and Rønsen (2004). Bernhardt (1991) referred to the Swedish experience as a positive example for other countries in Europe to follow, and according to Pinelli (1995) Sweden exemplifies the possibility of encouraging fertility increase in a country. The importance of institutional changes that facilitate women to combine the 
production and reproduction has even been stressed by Eurostat. In a number of population projections, this institution has made future fertility levels in EU countries depend on the possible implementation of such policies (Joshi 1996).

It is important to note that Swedish family policy never has been directed specifically at encouraging childbearing but instead have been aimed to strengthen women's attachment to the labour market and to promote gender equality. The focus has been on enabling individuals to pursue their family and occupational tracks without being too strongly dependent on other individuals or being constrained by various institutional factors. Policies are explicitly directed towards individuals and not towards families as such. In terms of childbearing, the goal is to enable women and men to raise the number of children they want to have. Surveys on young Swedes reveal that, on average, Swedish women and men aspire to have well above two children. In view of these results, Swedish authorities have become particularly concerned about childbearing dynamics in times of period fertility declines to far below the (population-replacement) level of 2.1 children per woman. This was the case at the end of the 1970s and, again, in the late 1990s. In both cases, the then low fertility triggered Swedish authorities to start investigations about what could be done to facilitate Swedish people having the number of children they claim they want to have. (For the latter investigation, see Swedish Ministry of Health and Social Affairs 2001.) On both occasions, the depressed fertility was seen to be a welfare issue, and the purpose of the investigations was to detect the kind of obstacles in society that hampered individuals from pursuing their desired life goals. Nevertheless, the desirability of higher fertility in Sweden was articulated more clearly during these two 
periods than during other calendar periods. In both cases, fertility started to increase again shortly after the investigations had been carried out ${ }^{2}$.

\section{CHILDBEARING TRENDS IN SWEDEN}

The general situation of fairly high Swedish fertility has been obscured by the fact that childbearing in Sweden has fluctuated that much in recent decades. A presentation of aggregate trends in childbearing in the four main Nordic countries as they show up in period Total Fertility Rates (TFR) reveals that Swedish fertility has exhibited a roller-coaster pattern (Hoem and Hoem 1996) with undulations around the average of the other Nordic countries (see Figure 1). The general picture of Nordic fertility is that of an increase during the 1980 s followed by a convergence between countries towards the present Nordic average of a TFR at 1.7-1.8 children per woman. In an international comparison, such a fertility level can be labelled as "highest-low": it is below the replacement level of 2.1 children per woman but still high as compared to many other developed countries.

Recent fluctuations in Swedish TFR values show an upward trend from 1983 to 1990 , a sharp drop from 1992 to 1997 , and a recovery from 1999 to the present day. (Monthly statistics from Statistics Sweden reveal that by the end of 2004 Swedish fertility was still increasing.) As fertility measure, however, the TFR is a very crude indicator. It is better suited to describe the completed childbearing of cohorts of women and men. In various publications, I have instead presented period trends in childbearing at different birth orders of women in Sweden (see Andersson 1999 with an update by Andersson 2004a) and other Scandinavian countries (Andersson 2002,

\footnotetext{
${ }^{2}$ The investigations have a historical predecessor in an ambitious investigation of fertility and family policies carried out by Myrdal and Myrdal during the 1930s. They resemble their predecessor in their "fertility-stimulating" effect: fertility started to increase shortly after the Myrdals published their work in 1934.
} 
2004b) by applying more advanced statistical methods to longitudinal populationregister data. Following an approach first suggested and described by Jan Hoem (1991, 1993a), this amounts to a modern version of indirect standardization, which allows for (i) the disaggregated description of demographic change, displaying trends in childbearing for a number of subgroups of women, (ii) the efficient use of available data, controlling for compositional changes over the different demographic categories at hand, and (iii) the use of a metric that is appropriate for a period-based analysis, giving information about changes in the propensity of the various groups of women to give birth.

Figures 2 and 3 provide the description of Swedish childbearing dynamics by means of a set of standardized annual birth rates of childless women and mothers, respectively. Figure 2 shows how first-birth fertility of women at ages below 30 decreased up to the mid-1980s. This decline was followed by a marked increase in the first-birth fertility of older women, together reflecting general postponement of entry into motherhood. During the Swedish baby boom of the 1980s, birth propensities also increased strongly for mothers at different parities (Figure 3) - as well as for the younger childless women. By contrast, the 1990s displayed strong declines in birth risks. As in the 1980s, these trends were followed by practically all demographic subgroups of women. In relative terms, the drops were strongest in first-birth rates of younger women and in third- and fourth-birth rates, whereas the decline in first-birth rates of older women was unimportant. Another clear trend reversal in birth propensities occurred after 1997. It is interesting to note that the increase in childbearing propensities in 1998 and 1999 is not evident in aggregated TFR data. The TFR of Sweden was recorded at 1.50 in these two years, the lowest level ever registered. With our presentation, we can get at the underlying dynamics of different 
subgroups of women, revealing with better precision when important changes in childbearing behaviour have occurred.

A comparison of childbearing dynamics in Sweden as expressed in Figures 2 and 3 with those of other Nordic countries reveals many similarities in patterns and trends and, again, that Swedish fertility has fluctuated more strongly than the corresponding birth rates of its neighbours (Andersson 2002, 2004b). The recent stability and similarity in the fertility of the other Nordic countries suggests that their fertility levels can be seen to a certain extent as a reflection of an underlying Nordic fertility regime at the beginning of the present century. Finally, the image of very volatile Swedish fertility withers if we instead look at the completed childbearing of Swedish cohorts of women. Statistics of that kind show that each female cohort born in 1920-55 achieved a final number of children within a narrow range of around 1.92.1 children per woman. (For further information on Nordic cohort fertility, see Frejka and Calot 2001 and Björklund 2005.) Such statistics rather indicate a long-term relative stability of Swedish fertility, with short-term period fluctuations occurring both around its own long-term cohort fertility level and around a recent average of Nordic period fertility.

\section{CHILDBEARING DYNAMICS IN SWEDEN}

Both the relatively high fertility of Sweden and its recent fluctuations need to be seen in the light of the specific setup of the Swedish welfare state. Its general orientation is directed towards the compatibility of family activities and the labour-force participation of women and men, the very existence being evident not only in the fairly high fertility but also in the strong labour-market attachment of Swedish women and men. The reconciliation of the family and working life of women is facilitated by (i) an individual taxation, which makes it less attractive for couples to pursue 
gendered segregation of work and care, (ii) an income-replacement based parentalleave system, which gives women incentives to establish themselves in the labour market before considering childbirth, and (iii) subsidized child-care, which allows them to return to work after a period of parental leave. A strong policy focus on gender equality aims not only at enhancing women's position in the labour market but also at encouraging men to be more active as to childrearing tasks within the family sphere.

In general, it is difficult to determine exactly to what extent family policies truly affect childbearing behaviour in a country. In empirical research, such policies would be treated as a macro-level factor, and it is often impossible to isolate the effect of one such factor on individual-level behaviour from the possibly competing impact of other macro-level factors. A careful cross-country comparison of gendered patterns in labour-market activity and of family dynamics within the different welfare-state regimes (Esping-Andersen 1990) of Europe nevertheless lends strong support to the role of political and institutional factors in explaining childbearing behaviour (for examples, see various contributions in Andersson and Neyer 2004). We find further support for the importance of such factors by a detailed examination of patterns in the childbearing of women in Sweden. Andersson (2000) and Hoem (2000) demonstrated, for example, that women well established in the labour market and with a decent level of earnings have much higher propensities to become a mother than childless women with a weaker attachment to the labour market. This pattern underlines that parenthood and labour-market activity by no means are considered by Swedish women as competing activities. The pattern is likely to be strengthened by the design of the Swedish parental-leave system, with its distinct income-replacement character, i.e., a leave allowance that constitutes $80 \%$ of a person's own earnings prior to 
childbirth. This system is likely to be conducive to higher fertility levels, in that it increases the compatibility of childbearing and employment. A decent level of income for a woman in Sweden is nowadays seen as a prerequisite for her childbearing and certainly not a hindrance to it. Evidently, this system is also sensitive to economic trends; Andersson (2000) and Hoem (2000) demonstrated that recent variations in the business cycle have fuelled the roller-coaster movements of Swedish fertility.

A study of childbearing patterns by the labour-market attachment of Swedish women and men by Andersson, Duvander, and Hank (2005) reveals further that the impacts of female and male earnings on a couple's childbearing behaviour turn out to be fairly similar. This suggests that there is at least some degree of gender equality in the way Swedish couples deal with their family building.

The importance of institutional factors in shaping childbearing behaviour is further underlined by a detailed study of the childbearing dynamics of foreign-born women in Sweden. If cultural factors instead were most important in shaping childbearing behaviour, then one would expect very different dynamics of women and men stemming from widely different countries of origin. However, the opposite holds. Swedish- and foreign-born women exhibit a remarkable similarity in both the way they respond to recent period effects in Swedish fertility (Andersson 2004c) and how their labour-market attachment affects their childbearing behaviour (Andersson and Scott 2005). We take this as a very clear indication that institutional factors seem to be far more decisive than cultural ones in shaping childbearing dynamics.

\section{CONSEQUENCES OF FAMILY POLICIES: FACTS OR ARTEFACTS?}

When studying the possible impact of family policies on childbirth one ideally considers the whole package of policies in their particular context. A specific policy cannot be seen in isolation, and its effect in another context might turn out to be 
completely different from that where it was first introduced. Nevertheless, it is worthwhile examining the extent to which specific policies can truly be shown to affect individual childbearing behaviour in a certain context. This can be achieved if a policy is depicted in such a way that there is some variation between individuals in how it actually is materialized. In this manner, I have studied how different aspects of the Swedish parental-leave and child-care systems have been related to the childbearing dynamics of Swedes.

The parental-leave and child-care systems of Sweden are certainly key elements of its family policy. The parental-leave system offers slightly more than one year of paid leave from work after the birth of a child, which can be shared between parents and used in a very flexible way. The allowance paid during leave is based on earnings attained prior to childbirth in the same manner as income replacement is offered to individuals on sick leave or unemployed. At present, the income is replaced with $80 \%$ of earnings up to an annual ceiling of around 32,000 Euro (counted as earnings before tax but after social-security contributions). In addition, the scheme offers generous opportunity to stay at home to take care of sick children after the parental-leave period is finished.

The parental-leave system of Sweden was established in the 1970s and extended in the 1980s, with the other Nordic countries following the same development but at a somewhat slower speed. A specific component of the present Swedish system, the so called "speed premium", was also introduced in the 1980s. It creates incentives to women to have their children at relatively short birth intervals (Hoem 1990, 1993b, Andersson 1999). A cross-country comparison of the period effects in childbearing of mothers in Sweden, Denmark, and Norway by the time since the last childbirth (Andersson 2002b, 2004) offers the rare case where a clear 
causal effect can be demonstrated of a policy intervention on the childbearing dynamics in a developed country.

Much of the present debate on the parental-leave system in Sweden focuses on the relatively low uptake of the leave of fathers (Haas and Hwang 1999, Sundström and Duvander 2002). Swedish fathers do take 10-15 percent of all parental leave, which is considerably higher than in any other country, but Swedish authorities see the slow progress towards a further increase in paternal involvement in the parentalleave scheme as being an obstacle to gender equality. It is also common to expect that increased paternal involvement in childrearing is related to higher fertility. A study by Duvander and Andersson (2004) suggests that there is indeed a positive but not a straightforward relationship between fathers' uptake of parental leave and Swedish couples' propensity to have another child.

In Sweden, public day care for children is regarded as an essential component of the overall welfare system and its direction towards a dual-breadwinner model, gender equality, and the promotion of same opportunities for children of all social backgrounds (Bergqvist and Nyberg 2002). The provision of public child care improved substantially during the 1970 s to 1990 s, when the expansion of such services became a generally accepted policy objective. At present, practically all children in Sweden have access to subsidized childcare of high quality. A study by Andersson, Duvander, and Hank (2004) examines if the local variation in child-care characteristics can be related to the childbearing dynamics of parents in different Swedish municipalities. They find no such indication and interpret the absence of effects as a reflection of the generally very appropriate level of child care in Sweden. They conclude that "despite some regional variation in the quantity, quality, and price of day care, the overall coverage with affordable, high-quality child-care opportunities 
is apparently on a sufficiently high level as to allow parents to make their fertility decisions relatively independent of the specific characteristics of their local area".

\section{FAMILY POLICIES AND FERTILITY: AN ASSESSMENT OF DIFFERENT POLICY OPTIONS}

In this review, I have demonstrated how childbearing patterns in Sweden are related to the setup of the Swedish welfare state. Policies aimed at strengthening women's labour-market attachment and at promoting gender equality have made it easier for women to combine work and family life. In such a setting, fertility has remained relatively high.

The policies that have been most important in creating such a setting are the specific combination of individual taxation, an income-replacement based parentalleave scheme, and a system of high-quality full-time day care. Together they support the existence of the present dual bread-winner model of Sweden. I have not considered the existing scheme of child allowances since the levels of such allowances do not largely deviate from the levels in other developed countries. While being helpful in alleviating some of the direct costs of having children, they are less likely to promote childbirth as such. It is doubtful that it is possible to simply pay people to have children by offering various allowances or tax deductions. In the Swedish context, childbirth is supported by providing an infrastructure that allows women and men to pursue their individual life goals in terms of family and professional life. In economic terms, Swedish families base their welfare on own earnings rather than on allowances.

An important aspect of Swedish policies is that they are directed towards individuals and not families as such. They have no intention of supporting certain family forms, such as marriage, over others. An analysis of crude birth rates and 
various other crude indicators of the family dynamics of European countries suggests that this might be a wise strategy if one is interested in higher fertility. There is a very clear pattern of countries with more traditional family behaviour, such as a high propensity for marriage, low divorce rates, and low levels of out-of-wedlock childbearing, having the lowest fertility while countries with greater diversity in their family dynamics have the highest fertility (Billari and Kohler 2004). Evidently, in a context that confines childbearing to conservative family forms, there always will be a fraction of the population that tries to avoid getting trapped in such a life situation. A persistent focus on gender equality in public as well as in private life (MacDonald 2000a,b) seems to offer a better strategy for policy makers in creating an environment where childbearing is not seen by women as a step towards reduced personal freedom.

A final suggestion based on our study is that the fertility levels of the Nordic countries at the beginning of the twenty-first century are useful as a benchmark when making forecasts about the fertility that is likely to appear when a society orients itself towards the reconciliation of the active labour-force participation of women and men to the activities and responsibilities of childrearing.

\section{ACKNOWLEDGEMENTS}

The author acknowledges support from the University of Hong Kong, the Division 2 of the Max Planck Institute for Demographic Research, and Susann Backer. 


\section{REFERENCES}

Andersson, G., 1999. “Childbearing trends in Sweden 1961-1997”. European Journal of Population 15: 1-24.

Andersson, G., 2000. "The impact of labor-force participation on childbearing behavior: Pro-cyclical fertility in Sweden during the 1980s and the 1990s". European Journal of Population 16: 293-333.

Andersson, G., 2002. "Fertility developments in Norway and Sweden since the early 1960s". Demographic Research 6(4): 67-86. Available http://www.demographic-research.org/Volumes/Vol6/4.

Andersson, G., 2004a. "Demographic trends in Sweden: An update of childbearing and nuptiality up to 2002". Demographic Research 11(4): 95-110. Available http://www.demographic-research.org/Volumes/Vol11/4.

Andersson, G., 2004b. "Childbearing developments in Denmark, Norway, and Sweden from the 1970s to the 1990s: A comparison". Demographic Research Special Collection 3(7): 155-176. Available http://www.demographicresearch.org.

Andersson, G., 2004c. "Childbearing after migration: Fertility patterns of foreignborn women in Sweden". International Migration Review 38(2): 747-775.

Andersson, G., A.-Z. Duvander, and K. Hank, 2004. "Do child-care characteristics influence continued child bearing in Sweden? An investigation of the quantity, quality, and price dimension”. Journal of European Social Policy 14(4): 407418.

Andersson, G., A.-Z. Duvander, and K. Hank, 2005. "Erwerbsstatus und Familienentwicklung in Schweden aus paarbezogener Perspektive“. In: Tölke, A., and Hank, K., eds, Männer - Das ,vernachlässigte' Geschlecht in der Familienforschung [Sonderheft 4 der Zeitschrift für Familienforschung]: 220234. Wiesbaden: VS Verlag für Sozialwissenschaften.

Andersson, G., and G. Neyer, eds, 2004. Contemporary Research on European Fertility: Perspectives and Developments. Edited Special Collection 3 of Demographic Research. Available http://www.demographic-research.org. 
Andersson, G., and K. Scott, 2005. "Labour-market status and first-time parenthood: The experience of immigrant women in Sweden, 1981-96". Population Studies 59(1): 21-38

Bergqvist, C., and A. Nyberg, 2002. "Welfare state restructuring and child care in Sweden”. In: Michel, S., and R. Mahon, eds, Child care policy at the crossroads: Gender and welfare state restructuring: 287-307. New York: Routledge.

Bernhardt, E., 1991. "Working parents in Sweden: an example for Europe?". In: Human Resources in Europe at the dawn of the $21^{\text {st }}$ Century: 231-254. Eurostat Conference, November 27-29, 1991, Luxembourg.

Bernhardt, E., 1993. "Fertility and employment". European Sociological Review 9: $25-42$.

Billari, F., and H.-P. Kohler, 2004. "Patterns of low and lowest-low fertility in Europe". Population Studies 58: 161-176.

Björklund, A., 2005. "Does family policy affect fertility? Lessons from Sweden". Journal of Population Economics: forthcoming.

Brewster, K., and R. Rindfuss, 2000. "Fertility and women's employment in industrialized countries". Annual Review of Sociology 26: 271-296.

Duvander, A.-Z., and G. Andersson, 2004. Leder delad föräldrapenning till fler barn? En studie om hur pappor och mammors föräldrapenninguttag påverkar benägenheten att skaffa ytterligare barn. Riksförsäkringsverket analyserar, 2004:15, Stockholm [Gender equality and fertility in Sweden: An investigation of the impact of the father's and mother's use of parental leave on continued childbearing].

Ellingsæter, A.L., and M. Rønsen, 1996. "The dual strategy: motherhood and the work contract in Scandinavia”. European Journal of Population 12: 239-260.

Esping-Andersen, G., 1990. The Three Worlds of Welfare Capitalism. Oxford: Polity Press.

Frejka, T., and G. Calot, 2001. "Cohort reproductive patterns in the Nordic countries". Demographic Research 5(5): 125-186. Available http://www.demographicresearch.org/Volumes/Vol5/5.

Haas, L., 1992. Equal Parenthood and Social Policy: A Study of Parental Leave in Sweden. Albany: State University of New York Press. 
Haas, L., and P. Hwang, 1999. "Parental leave in Sweden". In: Moss, P., and F. Deven, eds, Parental Leave: Progress or Pitfall?: 45-68. The Hague/Brussels: NIDI/CBGS Publications, Vol. 35.

Hoem, B., 1993. "The compatibility of employment and childbearing in contemporary Sweden”. Acta Sociologica 36: 101-120.

Hoem, B., 2000. "Entry into motherhood in Sweden: the influence of economic factors on the rise and fall in fertility, 1986-1997". Demographic Research 2(4). Available http://www.demographic-research.org/Volumes/Vol2/4.

Hoem, B., and J.M. Hoem, 1996. "Sweden's family policies and roller-coaster fertility". Jinko Mondai Kenkyu (Journal of Population Problems) 52: 1-22.

Hoem, B., and J.M. Hoem, 1999. "Fertility trends in Sweden up to 1996". Population Bulletin (United Nations) 40/41: 318-333.

Hoem, J.M., 1990. "Social policy and recent fertility change in Sweden". Population and Development Review 16: 735-748.

Hoem, J.M., 1991. "La standardisation indirecte améliorée et son application à la divortialité en Suède (1971-1989)". Population 46: 1551-1568.

Hoem, J.M., 1993a. "Classical demographic methods of analysis and modern eventhistory techniques". IUSSP: 22nd International Population Conference, Montreal, Canada, Volume 3: 281-291.

Hoem, J.M., 1993b. "Public policy as the fuel of fertility: effects of a policy reform on the pace of childbearing in Sweden in the 1980s". Acta Sociologica 36: 19-31.

Joshi, H., 1996. "Projections of European population decline: serious demography or false alarm?". In: Coleman, D., ed., Europe's Population in the 1990s: 222266. Oxford: Oxford University Press.

McDonald, P., 2000a. "Gender equity, social institutions and the future of fertility". Journal of Population Research 17: 1-16.

McDonald, P., 2000b. "Gender equity in theories of fertility transition". Population and Development Review 26: 427-439.

Moen, P., 1989. Working Parents: Transformations in Gender Roles and Public Policies in Sweden. Wisconsin: The University of Wisconsin Press.

Oláh, L.S., 2003. "Gendering fertility: Second births in Sweden and Hungary". Population Research and Policy Review 22: 171-200.

Pauti, A., 1992. “La politique familiale en Suède”. Population 47: 961-985. 
Pinnelli, A., 1995. "Women's condition, low fertility, and emerging union patterns in Europe”. In: Mason, K.O., and A.-M. Jensen, eds, Gender and Family Change in Industrialized Countries: 82-101. Oxford: Clarendon Press.

Rindfuss, R., and K. Brewster, 1996. "Childrearing and fertility". Population and Development Review, A Supplement to Vol. 22: 258-289.

Rønsen, M., 2004. "Fertility and family policy in Norway - A reflection on trends and possible connections". Demographic Research 10(10): 265-286. Available http://www.demographic-research.org/Volumes/Vol10/10.

Sundström, M., 1991. "Sweden: supporting work, family, and gender equality". In: Kamerman, S., and A. Kahn, eds, Child Care, Parental Leave, and the Under 3s: Policy Innovation in Europe: 171-200. Westport, Connecticut: Auburn House.

Sundström, M., and A.-Z. Duvander, 2002. "Gender division of childcare and the sharing of parental leave among new parents in Sweden". European Sociological Review 18: 433-447.

Sundström, M., and F. Stafford, 1992. "Female labour force participation, fertility and public policy in Sweden”. European Journal of Population 8: 199-215.

Swedish Ministry of Health and Social Affairs, 2001. Barnafödandet i fokus: Från befolkningspolitik till ett barnvänligt samhälle, DS 2001:57. Stockholm: Fritzes. 
Figure 1: Total Fertility Rate of Denmark, Finland, Norway, and Sweden, 1975-2004

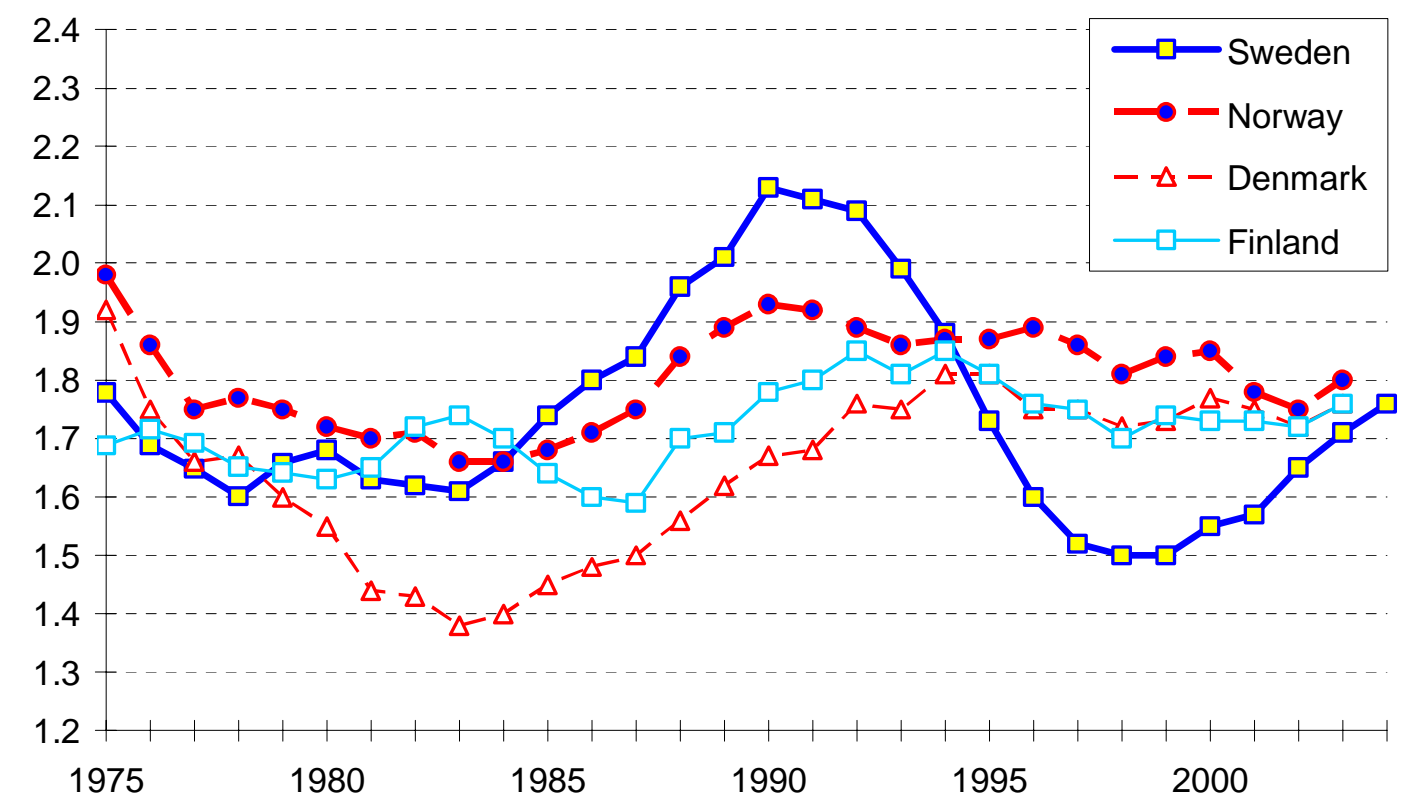


Figure 2: Standardized annual first-birth rates.

Swedish childless women, 1970-2002, by group of ages, standardized for age in single years.

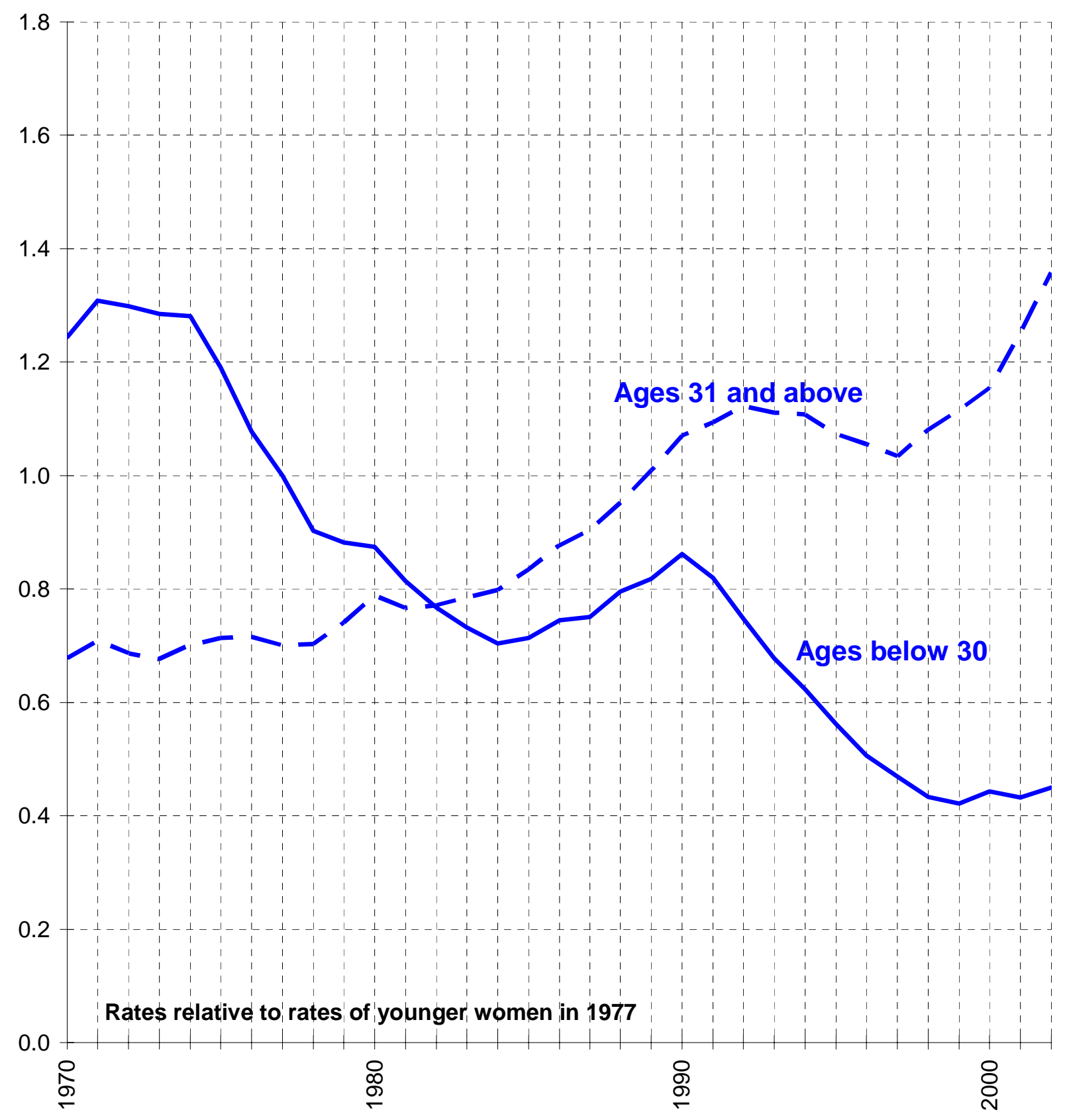


Figure 3: Standardized annual second-, third-, and fourth-birth rates.

Swedish mothers, 1970-2002, by birth order,



